\title{
WPS4005
}

\section{What Is Effective Aid? How Would Donors Allocate It?}

\author{
Charles Kenny ${ }^{\mathrm{i}}$
}

\begin{abstract}
There are significant weaknesses in some of the traditional justifications for assuming that aid will foster development. This paper looks at what the cross-country aid effectiveness literature and World Bank Operations Evaluation Department (OED) reviews have suggested about effective aid, first in terms of promoting income growth and then for promoting other goals. This review forms the basis for a discussion of recommendations to improve aid effectiveness and a discussion of effective aid allocation. Given the multiple potential objectives for aid, there is no one right answer. However, it appears that there are a number of reforms to aid practices and distribution that might help to deliver a more significant return to aid resources. We should provide aid where institutions are already strong, where they can be strengthened with the help of donor resources, or where they can be bypassed with limited damage to existing institutional capacity. The importance of institutions to aid outcomes, as well as the fungibility of aid flows, suggests that programmatic aid should be expanded in countries with strong institutions, while project aid should be supported based on its ability to transfer knowledge and test new practices and/or support global public good provision rather than (merely) as a tool of financial resource transfer. The importance of institutions also suggests that we should be cautious in our expectations regarding the results of increased aid flows.
\end{abstract}

World Bank Policy Research Working Paper 4005, September 2006

The Policy Research Working Paper Series disseminates the findings of work in progress to encourage the exchange of ideas about development issues. An objective of the series is to get the findings out quickly, even if the presentations are less than fully polished. The papers carry the names of the authors and should be cited accordingly. The findings, interpretations, and conclusions expressed in this paper are entirely those of the authors. They do not necessarily represent the view of the World Bank, its Executive Directors, or the countries they represent. Policy Research Working Papers are available online at http://econ.worldbank.org.

i Senior Economist, Infrastructure Economics and Finance, the World Bank (ckenny@worldbank.org). 


\section{What Is Effective Aid? How Would Donors Allocate It? \\ Charles Kenny}

\section{Introduction}

If all donors agreed on aid objectives and the methods to achieve them, we would only need one aid agency. That we have a growing multiplicity suggests that this is not the case. ${ }^{1}$ There are many potential goals for aid and little consensus around methods to maximize progress toward any particular goal. There are also considerable unknowns because aid projects and programs have been too little subject to rigorous monitoring and evaluation and because of the complexity of determinants of success and failure. Having said that, it appears that the quality of institutions is an important factor in determining the results of aid to governments, at least, and that there are a number of reforms to aid practices and distribution that might help to deliver a more significant return to aid resources. We should provide aid where institutions are already strong, where they can be strengthened with the help of donor resources, or where they can be bypassed with limited damage to existing institutional capacity. The importance of institutions to aid outcomes, as well as the fungibility of aid flows, suggests that programmatic aid should be expanded in countries with strong institutions, while project aid should be supported based on its ability to transfer knowledge and test new practices and/or support global public good provision rather than (merely) as a tool of financial resource transfer. The importance of institutions also suggests that we should be cautious in our expectations regarding the results of increased aid flows.

This paper opens with a discussion of various different objectives for aid. It then discusses weaknesses in some of the justifications for assuming that aid will foster development. It looks at what the cross-country aid effectiveness literature and World Bank Operations Evaluation Department (OED) reviews have suggested about effective aid, first in terms of promoting income growth and then for promoting other goals. This review forms the basis for a discussion of recommendations to improve aid effectiveness and a discussion of effective aid allocation.

\section{What Are We Trying to Maximize?}

Overseas Development Assistance is presumably designed at least in part to promote development in the recipient country. But this is both inadequate and underspecified. The definition of development is hardly a settled one, and development in the recipient country is not the only goal of ODA. In most of the recent literature on 'aid effectiveness' the assumption has been that effective aid is that which increases recipient country GDP per capita growth rates. But that is clearly only one indicator of success. We might be concerned with:

- Income growth in particular places and of particular people. In particular, we might care most about minimizing inequality or maximizing poverty reduction, perhaps minimizing those living on a dollar a day or two dollars a day, or perhaps 
with measures of the 'poverty gap' (the distance below a given poverty level). We may also care more about the incomes of those living close to us than those living further away. ${ }^{2}$

- Non-income factors in the recipient country such as starvation, education, health, democracy or stability. ${ }^{3}$

- Impacts for donor countries, in terms of guilt-relief, donor government political support at home or in the UN, or less threat of terrorism or environmental decay. ${ }^{4}$

- The maximizing of aid flows themselves, in particular flows through individual donor agencies.

Furthermore, our concern can be at the local, country or global level -we might be concerned with the 'fair' distribution of aid between countries as a good in its own right, for example. We might also be concerned with global public goods and regional or global recipients. Our discount rate in terms of concern regarding development today and potential development tomorrow might vary. ${ }^{5}$ A very high discount rate, arguably appropriate when many people worldwide are dying for simple lack of adequate nutrition, would suggest abandoning any concern about income growth and looking purely at increased present consumption as our measure of success.

Given all of these potentially divergent targets, more than a few of which appear reasonable, it may be there is no simple answer to the question 'is aid effective?' Having said that, and despite the fact that promoting GDP per capita growth may not be the area in which aid has performed (or should perform) most effectively, the next two sections will largely focus on this measure because much of the recent cross-country literature on aid effectiveness has taken it as the yardstick of success.

\section{Should Aid Work?}

It is not immediately clear why we would expect transfers received from rich countries to foster economic growth. After all, it is not the usual justification for income transfers within rich countries that they will lead to more rapid output growth amongst the poor at home. The usual argument involves equity concerns and ensuring a basic consumption package. An empirical exercise that suggested the largest welfare recipients in period one saw the fastest wage growth in period two in a group of OECD countries would create significant interest, but this author has not seen such a study. ${ }^{6}$

Most of the traditional arguments as to why aid should foster faster economic growth appear to have weaknesses on further examination. Filling an 'investment gap', improving the quality of investment or using aid to foster improved policies are all potential mechanisms, but there are reasons to doubt the efficacy of these mechanisms in many developing country circumstances. Furthermore, there are reasons that we might assume that aid dependency would create lower long-term growth prospects linked to a corrosive effect on institutions.

The oldest argument for 'why aid is different' is based on the financing gap model, suggesting that investment was the major cause of growth and that aid could provide 
investment resources not otherwise available to recipient countries. As a result, incremental capital-output ratios (ICORs), growth targets and 'investment gaps' provided the pseudo-science behind initial aid allocation levels and targets -including the ex-post justification for a 0.7 percent target for official aid flows from donor countries.

The simple investment-to-growth model is no longer in favor among development economists, however. Most evidence appears to suggest that productive investment is caused by economic growth as much as it is a cause and that investment is not the barrier to growth in regions such as Sub-Saharan Africa. ${ }^{7}$ (In a related literature, the evidence for investment-related poverty traps is also found to be weak. $)^{8}$

There is a further imperfect relationship between aid flows and investment, with some considerable amount of aid 'lost' in consumption. A recent metastudy of 43 papers examining the link between aid and accumulation found that, across the studies, aid had a small, statistically insignificant positive effect on investment and a small, statistically significant negative effect on savings. ${ }^{9}$ In one much-cited example, Bill Easterly notes that if "Zambia had converted all the aid it received since 1960 to investment and all of that investment to growth [following the ICOR model], it would have had a per capita GDP of about $\$ 20,000$ by the early 1990s. Instead, Zambia's per capita GDP in the early 1990 s was lower than it had been in 1960, hovering under $\$ 500 .{ }^{\prime 10}$

The second part of the original financing gap model justifying aid transfers involved inadequate private capital flows to cover the 'investment gap' between domestic savings and resources needed to promote rapid growth. Article III of the World Bank's Articles of Agreement suggests that the Bank should only lend to countries where it is "satisfied that in the prevailing market conditions the borrower would be unable otherwise to obtain the loan under conditions which in the opinion of the Bank are reasonable for the borrower," for example.

However, according to one recent analysis, the evidence is that the World Bank has neither stepped in to substitute for private international lending (providing more support to countries without access) nor ameliorated the failings of domestic markets (as measured by its failure to catalyze future private financing flows). ${ }^{11}$ Many aid recipients keep in place policies that deter foreign private investment (such as maximum FDI percentages in 'key sectors'), while most large middle income countries now have access to private markets at rates not outrageously higher those provided by the IBRD and at levels that dwarf available IBRD financing. One estimate is that the interest rate difference between IBRD and private loans to the World Bank's middle income clients has fallen from $12 \%$ in 1999 to $2 \%$ in 2005, and the Bank represents less than one percent of the net flows to the 27 borrowers that receive $90 \%$ of its loans. ${ }^{12}$

Furthermore, using the same model as used by the original academic justifications for the 0.7 percent figure but today's numbers regarding savings rates and GDP in developing countries and the GDP of rich countries, the need for external finance (public and private) suggested by the model for low income countries amounts to 0.03 percent of rich country GDP -considerably smaller than today's public flows. Adding middle-income countries 
to the model suggests that flows should be from poor to rich countries. The financing gap model is now neither empirically sound nor politically expedient, then. ${ }^{13}$

Perhaps aid flows are invested in better things? Certainly, the estimates of the economic rate of return of World Bank projects at the micro level in Africa compare favorably to research suggesting there is no link between average investment and output growth in Africa. Having said that, the weak correlation between aid flows and overall investment suggests that aid may be displacing local investment in strong projects, which is instead consumed (or at worst invested in white elephants). ${ }^{14}$ A piece of evidence that aid as a whole may not be improving the overall productivity of investments in many countries is that aid accounts for such a considerable percentage of total public investment in some countries. Nearly two dozen African countries already receive aid worth more than 50 percent of total public expenditures- and yet public investment apparently remains largely unproductive. ${ }^{15}$

Aid is also different from other transfers in that it tends to come with advice -including technical assistance regarding efficient expenditure of public resources. One way to measure the efficacy of this advice is to look at cases where aid flows are (supposedly, at least) conditional on such advice. ${ }^{16}$ The record of conditionality in terms of promoting improved economic performance, it may be fair to say, is patchy at best -and not primarily because reforms are not implemented. ${ }^{17}$ One recent study of repeated adjustment operations concludes that "there were relative successes and failures, but none of the top 20 recipients of adjustment lending over 1980-99 were able to achieve reasonable growth and contain all policy distortions." The study was unable to find a link to growth, positive or negative, of repeated adjustment lending. ${ }^{18}$ This may in part reflect a continuing consensus on policies ${ }^{19}$ maintained in the face of an overall weak relation between those policies and growth. ${ }^{20}$ There is mounting evidence that many of the factors that do promote stronger economic performance are difficult or impossible to change in the short term -factors including geography, demography and institutions. ${ }^{21}$

Related to this, there is limited evidence that aid considerably improves economic institutions over the short term. ${ }^{22}$ The impact of World Bank aid on institution building is itself particularly mixed, according to a number of sobering OED reports which conclude (inter alia) that " $[w] i t h i n$ just a few years, the Bank has developed and mobilized a variety of tools... that bring the quality of the public sector institutions into the spotlight. So far there is little evidence that governance is improving..."23 and that "[t]he Bank does not apply the same rigorous business practices to its capacity building work that it applies in other areas. Its tools... are not effectively used... most activities lack standard quality assurance processes..."24

Along with reasons to doubt aid's effectiveness in improving the quantity or quality investments or improving policy or institutional environments, there are reasons why we might expect aid to hurt long-term growth prospects. One such reason echoes once more the welfare debate in rich countries -the potentially debilitating effects of dependency. Dependency is a significant issue where, for a sample of African countries in a recent study, aid was equal to an average of 14 percent of GNP and 43 percent of government 
spending. ${ }^{25}$ Indeed, there is some evidence that aid flows are correlated with lower local tax collection, a declining quality of democratic institutions and weaker export performance in manufacturing. ${ }^{26}$ One recent study suggests that (in contrast to loans) grants reduce domestic revenue mobilization in particular in countries plagued by high corruption, where the decline in domestic collection is large enough to completely offset the increase in grants. ${ }^{27}$ Aid may also act as a prop to countries following inappropriate or unsustainable policies (to the extent we know what such policies are). ${ }^{28}$

In addition, aid can put a considerable burden on what limited institutional capacity is in place in a developing country. Many senior officials in Ghana spend as much as 44 weeks a year facilitating or hosting donor missions. Between 2000-2002 there were an estimated 1,300 donor-financed projects in Tanzania, 1,000 donor meetings a year and 2,400 reports due a quarter. ${ }^{29}$ This is a problem that is getting worse, with the number of projects launched by donors and reported to the Creditor Reporting System rising from around 10,000 in the $1995-7$ period to 27,876 in $2003 .{ }^{30}$ These projects suck not only time but also talent from governments. At one point aid-supported technical assistants in Tanzania were collecting twice the wages and salaries of all Tanzanian government employees combined. Pay scales 12 to 25 times the size of government rates in a recent donor-funded agricultural project in Kenya lured away seven government economists, for example. ${ }^{31}$ Aid also creates claims on future recurrent budgets -if it is financing the wrong thing, then, it can have a long-term negative impact on the efficacy of government financing. ${ }^{32}$

\section{When Does Aid Work (in terms of growth impact)?}

Given that a number of the traditional arguments for why there might be a link between aid flows and economic growth appear to be empirically weak, and that there are some reasons for thinking aid might actually slow growth performance over the long term, it should come as some comfort that the majority opinion in the aid and growth literature appears to be that aid, at least in certain circumstances, can promote growth. This result is, to bastardize Johnson, like a dog's walking on his hind legs. It is not done well --but you are surprised to find it done at all. One recent literature survey found 34 studies suggesting such a link (although it did miss out a number of prominent papers pointing the other way) while a metastudy of 68 papers suggests a small positive impact of aid although one that is statistically insignificant. ${ }^{33}$ Ignoring the issue of significance, the metastudy results suggest that aid has increased income per capita in poor countries as a whole by 20 percent since the 1960s. ${ }^{34}$

Most aid effectiveness studies tend to find little or no significant link between aid flows and economic growth in general, but many do find such a link if they split or condition results by recipient characteristics ('good policy' recipients, those with 'strong institutions' or 'non-tropical' recipients), by type of aid (netting aid for social sectors or particular donors) ${ }^{35}$ or by timing (post-cold war and before). As a result, it might be widely accepted that recent concessional loans (rather than grants) ${ }^{36}$ to rich countries ${ }^{37}$ currently receiving little aid, ${ }^{38}$ with strong ownership of proposed projects including co- 
financing $^{39}$ reasonable macro policies, strong institutions, cool climates and just coming out of a negative trade shock ${ }^{40}$ are likely to be some of the most positively associated with growth -in turn suggesting that Denmark's most effective (growth-promoting) aid policy would be to keep it all at home.

Having said that, many of the results appear fragile. A recent study examines the robustness of the policy, the policy and end of civil war, the diminishing marginal returns, the tropics, the small country/terms of trade/natural disaster and the negative export price shock relationships interactions with aid as causal elements in growth regressions. The study finds the aid-policy link the least robust while the aid-tropics link is the strongest. ${ }^{41}$ The good policy result is sensitive to different definitions of aid, different samples of aid and different definitions of 'good policy' all of which knock it from statistical significance. ${ }^{42}$

Perhaps unsurprisingly mirroring recent work on the causes of economic growth, the more robust aid-to-growth relationships appear to occur in non-tropical countries which also tend to be those with stronger institutions. This is a result echoed at the microeconomic level in studies of World Bank project outcomes. ${ }^{43}$ The extent to which institutional development matters to outcomes is suggested by an OED evaluation of infrastructure projects in Africa (where only 18 percent of projects were considered sustainable): "Infrastructure projects require a level of institutional capacity that simply does not exist in many Sub-Saharan African countries.”44

In this regard, it is important to note that institutions change slowly, and so that regardless of the level and persistence of aid flows there are likely to be limits to rates of progress. These limits are suggested by the fact that in the world as a whole over the 1970-1999 period only two countries grew as fast as would be required for Sub-Saharan Africa to grow to meet the poverty target of the Millennium Development Goals. ${ }^{45}$

The importance of institutions for performance may vary by type of aid, however. Within World Bank instruments, for example, technical assistance loans appear to have performed almost as well in countries with weak institutions as in countries with strong institutions. This as opposed to structural and sectoral adjustment loans in particular which performed far worse in weak institutional environments (investment loans falling somewhere in between). Less than 30 percent of Structural Adjustment Loans were judged satisfactory by the Bank's Operations Evaluation Department in countries that scored low marks on the Bank's Country Policy and Institutional Assessment ratings compared to 100 percent satisfactory outcomes in high CPIA countries. ${ }^{46}$

\section{Aid for Other Goals}

The preponderance of studies at the cross-country level have focused on income growth. Given the complex relationship between income growth and other potential targets for aid such as improved health or education, it is almost certainly not the case that aid attempting to maximize other targets would look the same as aid attempting to maximize 
GDP per capita growth. For example, while there is a strong correlation between income, health and education indicators across countries, nonetheless, we know that the link between income growth and growth in health, education and other indicators is very weak. $^{47}$ In Senegal between 1976 and 2002, GDP per capita has marginally declined. CO2 emissions have risen from 1,760 kilotons to 4,177 kilotons. At the same time, life expectancy has increased from 44 to 52 years and literacy from 19 to 39 percent of the population. The number of people in the country and so capable of enjoying life has increased from 4.5 to 10 million. As much as income change appears to have little to hold back health and education progress, health and education progress have apparently done little to foster growth to date. Meanwhile, the aid that Senegal has received (an average of around $\$ 600 \mathrm{~m}$ a year, or $12 \%$ of GNI, over $1976-2002)^{48}$ does not appear to have had a dramatic positive impact on growth rates. But it might have played a role in improving health and education -and at the same time potentially did so in increasing the country's $\mathrm{CO} 2$ output through power and transport projects.

Nonetheless, it is worth noting that similar lessons regarding complex causal chains and the importance of institutions appear to apply as much to non-income outcomes that might be targeted for aid as they do to the aid and growth literature. ${ }^{49}$ The strong role of institutions is suggested by the fact that conditions present at the time of initial colonization of countries in the developing World by European settlers has a significant correlation with current health outcomes in those countries. ${ }^{50}$

Given the importance of the institutional environment, it is again unsurprising that the few macro studies of aid effectiveness in terms of non-income outcomes also suggest that aid flows in general have a weak relationship with outcomes and that the only signs of a positive impact are where there are strong institutions in place. ${ }^{51}$ Similarly, the Operations Evaluation Department of the Bank found that borrower performance and the country institutional context (in particular as regards corruption) were the two most important factors in determining World Bank project success or failure in health projects. $^{52}$

The OED also notes that Bank-supported interventions in the social sectors "have frequently met or exceeded their physical and quantitative targets" but "they have often fallen short of bringing about qualitative and sustainable improvements in human development outcomes such as better learning achievements and improved health status." 53 Discussing projects in Africa, the OED concludes that only nine percent of education projects were rated as having significant institutional development impact and only 18 percent were judged sustainable. Only around 40 percent of health, nutrition and population projects were rated sustainable (primarily because "they focused on expanding infrastructure without sufficient attention to the fiscal implications of recurrent costs") and only 10 percent of projects were rated as having significant institutional development impact. $^{54}$ As few as 25 percent of health, nutrition and population projects supported by the World Bank worldwide achieved substantial institutional development impact. ${ }^{55}$

As to types of aid, again TA has a stronger performance than other Bank instruments in weak environments. More broadly, it is not clear that using non-government 
organizations to bypass the state is an effective response to the problem of limited overall aid effectiveness, in part because such bypassing does little to improve the institutional environment. ${ }^{56}$ Nonetheless, there is some suggestive cross-country evidence that aid funneled through NGOs has a statistically significant effect on infant mortality -as compared to no impact from (fungible) bilateral aid flows. ${ }^{57}$

\section{The Aid Literature and Aid Practice}

The cliché that we need not only more aid but better aid is widely supported by the literature. Donor performance matters to aid effectiveness. Simply improving design (including greater up-front analytical work) can have a significant impact on the outcome of World Bank projects, for example. ${ }^{58}$ This is likely to be particularly true where institutions are weak. But the results of the literature also suggest that different types of aid are likely to be more suitable to different client environments. Particular lessons arise from the facts that aid is fungible and that much of it relies for effectiveness on the presence of strong institutions. This in turn suggests both the importance of working with other actors than national governments and the importance of knowledge transfer over financial transfer as the key to successful growth -which itself suggests the need for an increased focus on monitoring and evaluation.

\section{Institutions and Fungibility}

'Traditional' project aid will only work where a lack of domestic or private foreign savings for quality investments is the significant barrier to increased output, and where aid resources are not fungible. It is not clear that this is the situation in the majority of developing countries today. Lack of savings has been relieved as a constraint in the many developing countries that have ample access to private financial markets. For many countries that do not have access to private flows, the larger problem is of limited returns to the investment already being undertaken due to weak institutions.

Furthermore, it appears that aid is highly fungible. Fungibility matters little when governments are largely investing in good projects. Indeed, where institutions are strong and aid flows are relatively small, it is likely that agreeing a general strategy for development up front with recipients and then giving general budget financing makes sense for much of donor support. ${ }^{59}$ This is, of course, the broad idea behind the poverty reduction strategy process, development policy lending and poverty reduction strategy credits. $^{60}$ Conversely, in countries with weak institutions, policy-based lending may be an unsuitable instrument. ${ }^{61}$

Regarding project aid, given the fungibility of aid, what matters at the project level isn't increasing funding for a particular activity or sector but to help improve service delivery and strengthen institutions -knowledge really may be the more significant channel through which projects cause long-term growth ${ }^{62}$ Technical assistance projects in support of institution-building, despite likely limits to significant improvement over the short term based on the slow pace of institutional development, is an activity worth 
supporting in weak and strong environments alike (its record appears similar in both cases, we have seen). But for individual investment activities, these are only likely to make sense in cases where the resultant project would be considerably differently designed (in terms of attempting new approaches or monitorability), or in support of global or regional public goods, where it is likely that there would be no project in the absence of aid.

As part of the knowledge agenda, there may be a considerable role for 'large scale pilots' -financing projects that are meant to demonstrate a better approach on a scale that is large enough to evaluate if sustainability is possible. Large scale pilots would evaluate new approaches to tackling development projects that were specifically designed to work within existing institutional and financial constraints and yet provide for better outcomes. Such an approach would apply in countries with both good and bad institutions.

With project aid, setting up project implementation units or working outside of governments may increase the likelihood of success of an individual project but have little if any effect on overall development impact. The World Bank model of working with governments may be important in limiting the potential institutional damage done by aid projects and perhaps supporting their development in these cases. At the same time, however, it holds project outcomes hostage to government performance. This is a tradeoff, best resolved by a focus on up-front project ownership and on institutionbuilding or project design that relies on reducing institutional capacity requirements.

Two methods for ensuring ownership (as well as reducing the risk of negative effects of dependency) are government leadership in design and government co-financing (which can take the form of accepting concessional borrowing for a project rather than receiving an outright grant). Of course, government delay or inability to co-finance as agreed in cases where such financing is up-front is a significant cause of project failure in itself, which again suggests a tradeoff, but one that might be mitigated through guarantee instruments and a greater willingness on the part of donors to cancel projects that have lost government support. ${ }^{63}$

To date, donors appear to be weakly placed to support the rapid development of strong institutional structures due both to a lack of knowledge about the right institutions for a particular environment and a lack of knowledge of (and access to) effective mechanisms to catalyze institutional change. Projects that rely on considerable institutional improvement during the life of (and fostered by) the project itself to maintain sustainability are clearly laden with risk. Having said that, given the considerable payoffs to success in institution building this should be an area where donors are willing to take risks and see comparatively high failure rates.

Models that incorporate significant institutional insulation, or that can achieve more within the same institutional constraints, will be very attractive. Output aid based approaches that rely less on public bodies and more on public contracts with a guarantee element to ensure sustainability and delivery may be one attractive option here. Indeed, output-based aid financing does not need to pass through governments at all. Suppliers 
could be directly compensated by donors for providing additional connections, for example. ${ }^{64}$ Given the likely corrosive effect of such bypassing on government institutional capacity, such bypassing should only occur in exceptional circumstances, and clearly on a grant basis.

It is not clear what the role is for donor-guaranteed lending at market rates (such as IBRD financing) in particular, given the fungibility of aid and middle-income country access to private finance. China's foreign reserves, at over $\$ 700$ billion, amount to nearly six times the total value of the World Bank's outstanding loans, for example. Unsubsidized financing is only likely to be attractive to both donor and recipient in cases where middleincome countries with good institutions find themselves temporarily in crisis. Perhaps this is unsurprising, as it was such situations that institutions such as the IBRD was set up to handle. There may also be a role to try large-scale pilots (even this would be subsidized rather than market interest rates) as part of a role in providing knowledge and ideas, and to support global public goods. Of course, if middle-income countries with strong institutions want unsubsidized loans, there appears little harm -and possibly some good- in giving such loans on a programmatic basis. Conversely, giving programmatic or project loans to middle income countries with weak institutions may be creating a disincentive to reform.

The flexibility of financing mechanisms might also be increased to encourage middleincome borrowing for projects that match donor development goals while encouraging ownership in low income countries. Given the importance of government ownership to project outcomes and the useful signaling power of cofinancing in this regard, moving to a full grants-based model for project aid should be resisted. Having said that, a sliding scale of interest rates may be more appropriate to funnel donor resources to areas and activities where they might have the greatest impact. Rather than a choice between unsubsidized interest rates or highly concessionary and grant financing, it might be advantageous to introduce a sliding scale of interest rates dependent on country conditions and project objectives. The subsidy element might be calculated as an interest rate (potentially negative) set at some percentage below what the country could get on the market, with the percentage dependent on project type. Poorer countries cofinancing innovative, well-monitored projects targeted at poverty reduction or global public good provision would receive loans the most heavily discounted from their market rates (so much so that interest rates could be significantly negative, as they are with World Bank IDA credits). Richer countries funding projects with little global public good or poverty impact would pay rates similar to those provided by the market. ${ }^{65}$ This would provide an incentive mechanism for countries to borrow for projects that fit most closely with donor objectives.

Again, it is important to note that the fragility of and contrary findings in the aid effectiveness literature suggest that it would be a mistake to lay down hard and fast rules. We should be careful of suggesting a limited role for aid to countries with weak institutions, for example -many projects do work even there. If donors only give aid to countries with both many poor people and very strong institutions, and were concerned with aid dependency, they wouldn't give much aid. Institutions will be weaker in poor 
countries, after all -this is an important reason that they are poor. ${ }^{66}$ The evidence does suggest that project success is harder in such environments, however, and this should be a spur to greater creativity (including risk taking) in types of support, and a recognition of the likely limits to rapid progress.

\section{Glocal Projects}

An important mechanism to improve quality of life in developing countries and especially in such countries with weak institutional capacity at the national level, is to use aid in support of technology development that will support poor people in particular as well as regional projects and projects at the subnational level which can leverage the presence of stronger institutional structures. There is a significant role for global projects aimed at alleviating problems in low income countries. As an example of a global aid project, aid could be used to commit resources for the purchase of vaccines for AIDS, malaria and TB as a spur to the private development of such a vaccine. The UK is likely to fund such an initiative. ${ }^{67}$ Given that technology transfer rather than income increases appears to be by far the major factor behind improved health outcomes in developing countries, ${ }^{68}$ there appears to be ample justification for such proposals at least in terms of maximizing the health outcome of aid. Other targets of aid for global public goods might be the more rapid development of robust, sustainable off-grid power solutions or agricultural research (on the model of CGIAR), for example. The success of some global public good programs (for example, vaccination) will require activities within individual countries. Global public goods provide some of the strongest rationales for working outside of governments if their capacity is limited, although it is impossible to implement such programs in the face of active opposition from governments.

While there is role for expanding global programs it should be pointed out that a recent OED estimate was that only about one third of the World Bank's global programs, covering global environment, agricultural and medical research, actually involve global public goods. ${ }^{69}$ Some other such programs might be better described as slush funds for support untied to PRSCs or Country Assistance Strategies. These may largely act as a vehicle to support projects in cases where there is little government buy-in for a program, although they can provide a fast-acting source of technical assistance. At the least, it would be worth clearly branding such funds and limiting them to pilot and TA activities.

As well as global programs, there should be increased support for cross-country regional programs in areas such as infrastructure and public health. ${ }^{70}$ There is also a role for increased support at the sub-sovereign level where particular state or local governments appear to have a stronger institutional base for successful investment or where there is an appetite for institutional reform. ${ }^{71}$

\section{Monitoring and Evaluation}

The donor record on monitoring and evaluation has been mixed. Even within the World Bank, because of low priority given to monitoring and evaluation the OED argues that "it 
is not possible to document the impact of the Bank's investment" in health, nutrition and population, ${ }^{72}$ for example. Incorporation of monitoring and evaluation in project design and support for projects that have been found robustly effective is likely to strengthen outcomes.

This may go beyond calls for an independent evaluation fund ${ }^{73}$ to a fund that can provide additional resources to projects to ensure that they are designed in such a way to improve the potential for evaluation. Donors might support a fund that supports the inclusion of randomized design and other 'gold plate' evaluation mechanisms in project design. Given that knowledge of successful project designs is a global public good, this would be a suitable global program.

Monitoring and evaluation is only of use if it informs future decision-making. One recent accounting of sustainable development projects subjected to randomized trial which show significantly positive outcomes found eighteen interventions with a cost (if extended throughout low income countries) of $\$ 34$ billion. The projects cover areas including education, nutrition, vaccination, malaria spraying, sexual health and fertilizer subsidies. ${ }^{74}$ That there are underfunded, tested models for projects while there are numerous projects being funded without any level of evaluation suggests that both monitoring and evaluation activities and the incorporation of lessons remains undersupported. ${ }^{75}$

\section{What Is an Efficient Cross-Country Allocation of Aid?}

Because of the multiple aims of aid, the many different levels of effectiveness and the considerable uncertainty surrounding results in the literature, there is undoubtedly no one right answer to levels of aid allocation between countries. For example, many complained in the immediate aftermath of the Asian Tsunami that too much aid was going to the tsunami victims rather than to malaria TB or AIDS prevention. These three diseases kill more than a million each year, as compared to the tsunami, which killed somewhere in the region of 200,000 people in a one-off event. This is based on an (arguable) assumption that aid allocation should be calculated on some measure of disability-adjusted life years involved. Furthermore, given reconstruction (shockrecovery) has a better record than development efforts in general (compare the Marshall plan to aid to Africa), that the tsunami had an impact on countries which have stronger institutions than countries with the highest infection rates of the big three diseases, that common aid-financed interventions in support of reduced AIDS and malaria burdens (condoms, bed nets) appear to have had limited impact to date and so on, it might be that the 'excess' aid to tsunami-affected countries would have a bigger impact on improving lives than aid spent on 'underfunded' AIDS, malaria and TB interventions.

Even if one is a strong believer in 'needs based' aid flows, the definition of need can dramatically impact where one believes aid should go. Currently, Sub-Saharan Africa (SSA) gets about 23 percent of total net official aid, while East Asia gets around 15 percent of aid flows (see Table One). Imagine our only criterion for per capita aid 
allocation was to give aid to countries based on the number of people they hosted living on less than \$2 a day. Sub-Saharan Africa would get 17 percent and East Asia 31 percent. If our criterion was to distribute aid to countries hosting those living under one dollar a day, Sub-Saharan Africa would get 26 percent of aid flows and East Asia would get 23 percent. If we weight by the dollar poverty gap index, SSA would get 33 percent and East Asia 20 percent. $^{76}$ Finally, if we apportioned aid according to population living in countries in which governments contracted zero in private external long-term loan commitments in 2002, 47 percent of aid would go to Africa and 15 percent would go to East Asia.

If one is a strong believer in the impact of institutional and policy factors on aid effectiveness, one's optimal aid allocation strategies might also look markedly different from current levels. Imagine our only criterion for per capita aid allocation (beyond developing country status) was macroeconomic management as measured by average inflation being below 10 percent 2000-2003. Nine percent of aid flows would go to Africa and 43 percent would go to East Asia. If our only criterion for per capita aid allocation was institutional strength as measured by the proportion of managers surveyed who ranked corruption as a major constraint to doing business in a country being below 30 percent 2000-2003, 0.3 percent of aid would flow to Africa and 75 percent of aid would go to East Asia.

One attempt to combine the two needs and abilities approaches appear to weight aid flows towards Asia. Taking policy-aid interaction coefficients from a growth regression and mapping these onto a growth to poverty reduction coefficient based on current national incomes and income distributions, 'correct' allocation of aid would increase the numbers lifted out of poverty each year through the use of aid from 30 million to 80 million, and $40 \%$ of the change would be accounted for by increased aid flows to India and China. $^{77}$

However, given the fragility of aid effectiveness results and their excess concentration on just one outcome, we really don't (can’t?) have a strongly-based empirical justification for any particular country-based aid allocation. Again, there is no one answer to the question 'have we got better at giving 'good' aid. The World Bank, for example, has not got any better at giving aid to countries with good governance scores, a potentially worrying finding from the point of view of outcome effectiveness but potentially sensible from the point of view of equity. ${ }^{78}$ Even if we agree on a particular outcome we wish to maximize, the most efficient allocation of aid will depend on the parameters as to what that aid can look like. It will also depend crucially on a host of unknowns as to payoffs from different types of support provided through different mechanisms to different actors at the local, national, regional or global level.

Nonetheless, the results may suggest that an increase in aid that looks the same as today's flows might have a limited impact on the countries that we wish to help the most -that for aid increases to have the maximum effect, they need to be more creatively used. This confirms what we have always known -giving aid to a kleptocracy will likely do little good. Giving that same aid to a cross-country effort to control river blindness ably 
backed by governments and NGOs and strongly supported by the local population, can make a real difference to the quality of life of hundreds of thousands.

In a new model for aid, country allocations based on a combination of population, income, and policy or institutional stance make little sense for non-programmatic aid. Project aid should be opportunistic, working with national governments -or other levels of government or non-government organizations-when there organizational support for a new approach that might deliver considerably improved results and for strong monitoring of such results. To provide for greater flexibility in allocating such support where it could do the most good, project aid resources might be apportioned at the regional rather than country level, in addition to global-level allocations for support of non-country-based global public good support (such as vaccine development).

Table One: Allocating Global Aid

\begin{tabular}{|c|c|c|}
\hline Distribution Mechanism & $\begin{array}{l}\text { Share of Aid To... } \\
\text { Sub-Saharan Africa }\end{array}$ & East Asia \\
\hline Current distribution & 23 & 15 \\
\hline \multicolumn{3}{|l|}{ Need } \\
\hline $\begin{array}{l}\text { Equal flow per person in country living on } \\
\text { less than } \$ 2 / \text { day }\end{array}$ & 17 & 31 \\
\hline $\begin{array}{l}\text { Equal flow per person in country living on } \\
\text { less than } \$ 1 / \text { day }\end{array}$ & 26 & 23 \\
\hline $\begin{array}{l}\text { Flow per person weighted by dollar poverty } \\
\text { gap index }\end{array}$ & 33 & 20 \\
\hline $\begin{array}{l}\text { Equal per capita flows to all developing } \\
\text { countries where governments contracted zero } \\
\text { in private external long-term loan } \\
\text { commitments in } 2002\end{array}$ & 47 & 15 \\
\hline \multicolumn{3}{|l|}{ Ability } \\
\hline $\begin{array}{l}\text { Equal per capita flows to all developing } \\
\text { countries with inflation }<10 \text { percent } 2000 \text { - } \\
2003\end{array}$ & 9 & 43 \\
\hline $\begin{array}{l}\text { Equal per capita flows to all developing } \\
\text { countries where proportion of managers } \\
\text { rating corruption a major constraint to doing } \\
\text { business }<30 \% 2000-2003\end{array}$ & 0.3 & 75 \\
\hline
\end{tabular}

\section{Conclusion}

Overall economic growth was probably never a good metric for aid effectiveness. The aid effectiveness literature may have flogged to death the wrong horse. The recent (broader) results focus of aid agencies toward better monitoring of project impact on a 
range of indicators related to the Millennium Development Goals is surely a step in the right direction in this regard, as is work looking at the whole results chain between project outcomes and macro results.

This work has only recently begun, but from what we know to date, a revised justification for aid might rest on three pillars: (i) increased government spending financed from outside in the presence of strong institutions improves outcomes; (ii) better-designed projects even in weak institutional environments can improve outcomes; and (iii) global public goods are likely to be underfunded at the national level. This suggests a role for (i) program aid where institutions are strong, (ii) project aid that focuses on new approaches that have government commitment in both strong and weak institutional environments; (iii) TA for capacity building and; (iv) project aid for global public goods (see Table Two). All four activities might be carried out with the support of subnational or regional institutions as well as non-government actors. But given the importance of institutions to development, aid should either achieve more with the same institutions or improve institutional structures, and a Hippocratic principal regarding government institutions (first do no harm) should be central.

If a donor agency is focused on maximizing the scale of resources which flow through the institution, it would attempt to be relatively agnostic in terms of methods and distributions to maximize impact. Of course, this 'aid dependency' of the agency itself would reduce aid effectiveness. This does suggest the importance of moving away from a model that emphasizes outflows as the index of success. It is clear that only for certain countries is maximizing aid flows a suitable target. There may be increased roles for funding in certain places, but it is likely that successful knowledge transfer (hard though this is) will have a larger impact on development prospects than greater aid flows.

Donors might take more risks. Donor financing might be seen as a tool to allow for experimentation in an environment of scarce resources. This experimentation (suitably monitored) should focus on achieving improved outcomes in environments of limited institutional (and financial) capacity, as well as on strengthening institutions themselves. Donors might more actively seek out capable institutions at subnational (and nongovernmental), regional or international levels that could deliver development results, rather than focus so heavily at the national level.

At the same time, a focus on institutional and geographic determinants of aid effectiveness suggests the need for caution in our estimation of what aid can achieve in the short term in terms of growth impact. If 'development as a whole' is a slow process dependent in significant part on institutional change, there is a danger in treating development problems as 'crises' and responding with emergency interventions that will have low impact. Donors might also explicitly recognize both tradeoffs and unknowns tradeoffs between equity and efficiency, results today and capacity tomorrow, for example. A recognition of such tradeoffs would help to set more realistic expectations may also lead to re-prioritization of interventions. 
For example, the 2004 World Bank Global Monitoring Report suggested that $\$ 30$ billion in extra aid could be effectively used today by developing countries rising to $\$ 50$ billion in they introduced policy and institutional reform. If these numbers are taken at face value, an effort to increase aid flows to developing countries by $\$ 50$ billion next year to speed growth would likely lead to wasted aid. ${ }^{79}$ In a narrow growth-promoting sense this might suggest caution in moving towards an International Finance Facility model which would increase aid over the short term at the expense of significantly lower resources over the longer term, with a net value of interest payments of over $\$ 200$ billion in interest charges. ${ }^{80}$ It may even be that donors should examine the potential for direct cash payments to poor people in developing countries if there is significant pressure to increase resource transfers tomorrow. Such payments may have a more direct impact on poverty than greater flows through weak institutional structures. ${ }^{81}$

At the same time, it is important to remember that we are setting the wrong standard when we say aid must lead to income growth to be considered a success. Aid should lead to adequate consumption, to longer life, better education and a range of other outcomes to be valued in their own good. Viewed through that lens, it may well be that aid has had many more successes than we give it credit for, that different allocations of aid would lead to dramatically improved outcomes and that front-loading may be more justified.

Our focus for aid, perhaps, should be in maximizing outcomes we value in their own right (longer life, literacy) through proven techniques subject to (preferably repeated) rigorous, credible, independent evaluation. ${ }^{82}$ It may be that such interventions will lead to economic growth -but even if they do not, it would be hard to argue that the money has been wasted. There are a number of such interventions that remain underfunded by donors, which is a strange outcome given their comparative chance of success.

Table Two: Aid by Income and Institutional Strength

\begin{tabular}{|l|l|l|l|}
\hline \multicolumn{2}{|c|}{ LICs } & \multicolumn{2}{c|}{ MICs } \\
\hline Weaker Institutions & Stronger Institutions & Weaker Institutions & Stronger Institutions \\
\hline Significant & Budget support & Analytic/consensus & Large scale pilots \\
analytic/consensus & Analytic/TA & building & (with cofinancing) \\
building/TA & Large-scale pilots & Local/regional TA & Crisis budget \\
Local/regional & (with cofinancing) & & support \\
work? & Regional/global & & Analytic work \\
NGOs & public good & & TA \\
Internatiuonal & financing & & \\
support & & & \\
"Insulated" & & & \\
investments with & & & \\
cofinancing. & & & \\
Direct payments to & & & \\
the poor? & & & \\
\hline
\end{tabular}




\section{Endnotes}

${ }^{1}$ Harford, Hadjimichael and Klein (2004) calculate that the aid flow Herfindahl Index has declined from 0.5 and above in the 1950 s to 0.1 today.

${ }^{2}$ EU aid to the middle income countries of its 'near abroad' accounts for 40 percent of total flows, for example (Lankester, 2004). A 'gravity model' of aid flows might be interesting in this regard.

${ }^{3}$ Despite a widespread simplifying assumption in much of the MDG costing literature that aid used to meet Goal One of halving global income poverty at a dollar a day can be the 'same aid' as that used to meet the other goals, it is by no means clear that aid to maximize education or health returns would look the same or go to the same places as aid to maximize income growth. The simplifying assumption is suggested by (not least) Clemens, Kenny and Moss (2005).

${ }^{4}$ Alesina and Dollar (2000) note that aid flows are significantly determined by colonial pasts and political alliances. Using an African sample, Brautigam and Knack (2004) report that small, poor, peaceful countries with a Belgian or Portuguese colonial history get more aid, but the status of governance in a country does not matter. See also Moss, Roodman and Standley (2005).

${ }^{5}$ The importance of discount rates in discussions of aid flows has focused around funding projects to delay or mitigate the effects of global warming -see the discussion in William Cline's paper Meeting the Challenge of Global Warming presented to the Copenhagen Consensus Meetings. But imagine also disaster relief -we may be willing to do long-term institutional damage by working outside government agencies in order to the short term good of saving lives more rapidly, for example.

${ }^{6}$ This despite a more favorable national institutional environment in OECD countries, distance from the tropics, the lack of civil wars and so on, that one might have thought would make the likelihood for welfare to income growth relationship within rich countries greater than that for an aid to growth link across countries.

${ }^{7}$ Kenny and Williams (2001), Easterly, Pack and Devarajan (2003). A good example related to investment in physical infrastructure of school construction suggests that if rural people in a sample of 22 developing countries all lived right next door to a school it would increase attendance from 50 to 53 percent (Filmer, 2004).

${ }^{8}$ Easterly (2005) finds no evidence in support of a Rostowian model of takeoff backed by high investment -indeed he notes that there is little evidence either for poverty traps (zero growth over long periods), nor of 'takeoffs' from such traps (from zero to 1.5 percent or above growth over a long period) -with only a few East Asian countries qualifying since the Second World War. Furthermore, takeoffs do not appear to be associated with preceding periods of higher investment.

${ }^{9}$ The study is Doucouliagos and Paldam (2005b). They find a small significant effect of aid on investment in Latin American and Asian subsamples (where a one point rise in aid as a percentage of GDP would raise investment by around 0.2 percent of GDP). One early study that found most aid went to consumption, not investment was Boone (1996). More recently, Durbarry (2004) argues that most aid did finance consumption prior to 1980, but since then it has financed investment.

${ }^{10}$ Easterly (2003).

${ }^{11}$ Clemens (2002). See also Banerjee and He (2005).

${ }^{12}$ Lerrick, (2005).

${ }^{13}$ See Clemens and Moss (2005). Having said that, the 0.7 percent target has always been a politicallymotivated target, and in that role it may well be considered a success.

${ }^{14}$ Feyzioglu, Swaroop and Zhu (1998) suggest that concessionary loans to a particular sector do not significantly increase spending in that sector (see also World Bank, 1998). At the micro level, van de Walle et al (2005) do find that, depending on their technique, a World Bank project's net contribution to rehabilitated road increments may be as high as 66 percent (i.e., only one third of the aid displaced local spending).

${ }^{15}$ Moss (2005).

${ }^{16}$ One might want to argue that technical advice at the micro level has a better track record, but it can just as easily be the wrong advice or advice that is comparatively useless given macro factors. Technical support to encourage better network design for a state-owned fixed-line telecoms company in Africa, for example, would in the majority of cases be like rearranging deckchairs on the Titanic. 
${ }^{17}$ A recent review of IMF conditions in adjustment operations found that as many as 65 percent of the conditions were implemented. Nestmann and Weder (2002). A review of the Millenium Challenge Corporation suggested that recipients implemented more 'sound' policies than they would have done otherwise, but there was no corresponding rise in the growth rate (Johnson and Zajonc, 2006).

${ }^{18}$ Easterly (2002). He notes the 30 IMF and World Bank adjustment loans to Argentina over 1980-99 and the 26 adjustment loans to Cote d'Ivoire and Ghana in particular. This is only one in a long line of studies to come to a similar conclusion. Indeed, Przeworski and Vreeland (2000) argue that participation in IMF programs has a short term negative effect. On leaving they grow faster, but not as fast as they would have done without entering in the first place. See also the review of studies in Butkiewicz and Yanikkaya (2005) and their own results which suggest IMF lending slows growth and reduces investment in low income countries and has no effect elsewhere, and Dreher (2006) again with similar results.

${ }^{19} \mathrm{~A}$ review of World Bank Country Assistance Strategies found that over 90 percent of evaluated CASs recommended the same growth strategy: macro-stability, liberalization, and trade and tariff reform (OED, 2000b).

${ }^{20}$ See Kenny and Williams (2001) on the weaknesses in growth theories focusing on investment in human and physical capital and policies in areas such as trade and taxation.

${ }^{21}$ The recent outpouring of studies on institutional and geographic factors behind growth includes Easterly and Levine (2002) who find that institutions dominate policies and initial conditions in determining growth outcomes, but that institutions change very slowly.

${ }^{22}$ Coviello and Islam (2006).

${ }^{23}$ OED (2004) which also suggests regarding programs that promote empowerment "both the intended and actual poverty impact of this type of intervention remain to be demonstrated."

${ }^{24}$ OED (2005a). See also OED (2005b) on investment climate work: "World Bank Group strategies for improving the IC [investment climate] have suffered from a lack of knowledge about what types of institutional arrangements will work... The feasibility of reform depends on the political economy of the reform process...”

${ }^{25}$ Brautigam and Knack (2004).

${ }^{26}$ Rajan and Subramanian (2005a) find evidence that countries which receive more aid see a decline in labor-intensive and tradeable industries in their manufacturing sector because of the real exchange rate over-valuation caused by aid inflows. McGillivray (2005) cites studies that find a negative relationship between aid flows and tax revenues (although Feyzioglu, Swaroop and Zhu (1998) is one study that points the other way). Djankov, Montalvo and Reynal-Querol (2005) find that foreign aid has a negative impact on democracy (although Dunning (2004) notes that aid is positively related to democracy in Africa in the post-Cold-War period). Svensson (2000) argues that the negative institutional impact of aid is worse in countries with high ethnic fragmentation.

${ }^{27}$ Gupta, Clements, Pivovarsky and Tiongson, (2003). See also Moss et. al. (2006) and Brautigam and Knack (2004). Brautigam and Knack find aid associated with both weaker governance (contra Goldsmith, 2004) and lower tax effort in Africa that exactly offsets aid flows, although with suggestive evidence of a reduced impact in the 1990s.

${ }^{28}$ Knack (1999). He also suggests that aid was a source for subsidies to inefficient parastatals in Tanzania in the 1970s and 1980s.

${ }^{29}$ Knack and Rahman (2004) find that greater donor fragmentation leads to declines in bureaucratic quality.

${ }^{30}$ Roodman, 2006.

${ }^{31}$ Brautigam and Knack (2004) and Birdsall (2004). A 1989 donor study quoted Brautigam and Knack suggested cutting the number of aid projects from 800 to a more manageable 400 in a post-crisis country instead the number rose to 2,000 by 1992 .

${ }^{32}$ Given that much aid is delivered outside the budget process (70 percent in the case of Tanzania in the mid-1990s), it may be that much aid is going to projects that may (correctly) be less than a government priority (Brautigam and Knack, 2004)

${ }^{33}$ The survey is McGillivray (2005) -- but he does fail to cite a number of studies that do not find any link -for example, Rajan and Subramanian (2005b). The metastudy is Doucouliagos and Paldam (2005a). They find that 46 percent of their sample were able to find a statistically positive effect but also find that the studies with the larger samples as well as more recent studies both find smaller correlations between aid and growth, suggesting to them that the increasing number of observations is making data mining increasingly difficult, and (so that) the statistical insignificance of aid on growth may turn out to be more 
robust. A similar result to McGillivray’s appears when looking at World Bank lending alone Butkiewicz and Yanikkaya (2005).

${ }^{34}$ Doucouliagos and Paldam (2005c). That aid is at least sometimes associated with better performance may make aid a stronger contender for additional funding that debt relief in terms of growth impact $(\$ 100$ billion in debt relief for low income countries to date does not appear to have altered public spending, investment rates, the quality of policies and institutions or growth outcomes according to Kraay and Chauvin, 2005).

${ }^{35}$ Clemens, Radalet and Bhavni (2004) argue that budget and balance of payments support, investments in infrastructure and aid for productive sectors does appear to have a short-term impact on output, with a $\$ 1$ increase in aid raising output (and income) by $\$ 1.64$ over four years (see Reddy and Minoiu, 2006, for a different disaggregation technique which produces a similar result). And yet Hanmer et. al. (2003) find that aid that supports vaccination programs probably works, and there is plentiful evidence that some health interventions have been great successes -see also Levine (2004).

${ }^{36}$ Klein and Harford (2005).

${ }^{37}$ Ruhashyankiko (2005) finds aid is less effective in poor countries. Dollar and Levin (2005) find that, all else equal, World Bank projects in Africa have a lower success rate than elsewhere. Nonetheless, Gomanee et. al. (2005) find that aid is significantly related to growth for a subsample of Sub-Saharan countries.

${ }^{38}$ McGillivray suggests that the evidence from a number of studies suggests that diminishing (to the point of negative) returns "is a seemingly highly robust finding" somewhere between 15 and 45 percent of GDP. See also Doucouliagos and Paldam (2005c) who find some support for the model although they suggest it may reflect "the mining of an arbitrary quirk in the data" -in which regard see Mwanza, (2004).

${ }^{39}$ Banerjee and He (2003), OED (2005c), World Bank (1998). This applies as much to policy-based lending as project-based, with the $\operatorname{OED}(2000 \mathrm{a}, \mathrm{b})$ finding that reforms supported by the Bank are more likely to be sustained if there is consensus within countries and between countries and the Bank on the importance and direction of those reforms.

${ }^{40}$ Collier and Dehn (2001). Much like Marshall aid, this may reflect aid going to countries where income levels are tepmporarily below the level that would be 'expected' given the strength of their institutions.

${ }^{41}$ Roodman (2004). Doucouliagos and Paldam's (2005c) metastudy also rejects the significance of the good policy result. McGillivray (2005) quotes eight studies (with six authors) that find an aid-policy link and 26 that find no link. Doucouliagos and Paldam's (2005a) metastudy does suggest that aid to Asia and aid since the 1970s is more significantly related to growth than other aid.

${ }^{42}$ See Easterly, Levine and Roodman (2003).

${ }^{43}$ Dollar and Levin (2005) argue that institutional strength is a significant determinant of World Bank project outcomes (see also Wane, 2004).

${ }^{44}$ OED (1999c).

${ }^{45}$ Clemens Kenny and Moss (2005b).

${ }^{46}$ OED (2001). This may reflect excessive optimism about how much improvement a SAL could induce, nonetheless, the particularly poor performance of structural adjustment loans where they are probably most needed is a sad irony and supports the decision to abandon such lending.

${ }^{47}$ Easterly (1999), Kenny (2005).

${ }^{48}$ Based on WDI data.

${ }^{49}$ Regarding complex causal interactions, for example, Kremer and Miguel (2001) link de-worming to school attendance, while Ranis and Stewart (2001) find health expenditures don’t appear to improve outcomes, but expenditure on increasing female primary enrollments does.

${ }^{50}$ Kenny, (2005). As a recent example, the partially aid-funded effort to eliminate polio worldwide has been a huge success -in 1980, the disease disabled over half a million people each year, by 2000 it had been all but eradicated. But recent outbreaks in countries formerly polio-free have stricken hundreds including 225 children in Indonesia — because of a strain emerging from Kano, in Northern Nigeria. There, the governor of the state banned polio vaccinations on the grounds that they were part of a plot to sterilize African girls.

${ }^{51}$ Regarding the outcome of aid financing, McGillivray (2005) cites some studies that look at the impact of aid on health and education expenditure and finds suggests there is some (weak) evidence that aid results in higher expenditures, but Pritchett et. al. (1998) note the weak relationship between health expenditures and outcomes. Perhaps partially as a result, Kenny (2005) cannot find robust links between aid flows and 
health and education outcomes. Having said that, again echoing the findings on aid and growth, some studies have found a conditional impact of aid flows in good policy and institutional environments (World Bank, 2003).

${ }^{52}$ OED (1999b).

${ }^{53}$ OED (2004). See also Bhaumik, 2005.

${ }^{54}$ OED (1999c).

${ }^{55}$ OED (1999a).

${ }^{56}$ For example, Live-Aid supported NGOs in the forced resettlement and 'villigization' of up to 3 million Ethiopians during the 1984-85 famine. Oxfam and others turned a blind eye to the resettlement program despite the fact that it accounted for 50,000 or more deaths.

${ }^{57}$ Masud and Yantcheva (2005). See also Boone (1996).

${ }^{58}$ Wane (2004), World Bank (1998), OED (2003).

${ }^{59}$ See Cordella and Dell'Ariccia (2003).

${ }^{60}$ Originally suggested in Kanbur and Sandler (1999).

${ }^{61}$ The recommendation of OED (2000b).

${ }^{62}$ Suggested by World Bank (1998).

${ }^{63}$ Another method to ensure ownership would be to follow a 'foundation' approach, where donors would respond to proposals from governments rather than themselves proposing and shaping programs

(Suggested by Birdsall, 2004). It is not clear how well this would work for large pilot or global public good projects, however.

${ }_{64}^{64}$ Meltzer (2000) suggests a similar approach.

${ }^{65}$ The argument that IBRD can provide long term financing for human development which is not available through markets is weak. The significant costs of human development are recurrent, and need to be financed through recurrent budgets, suggesting that investment financing is an unsuitable support mechanism.

${ }^{66}$ Sachs et. al. (2004) argue that African institutions are no worse than would be expected given their income levels -although note that they assume income levels cause institutions with no feedback from institutions to income.

${ }^{67}$ Barder (2005). See Fink and Bell (2004), for a theoretical discussion of the benefits of considerably increased global funding for vaccine research specific to developing country diseases.

${ }^{68}$ Kenny, (2005).

${ }^{69}$ OED (2005d).

${ }^{70}$ Suggested by Birdsall (2004).

${ }^{71}$ As recommended in the Bank's MIC financing task force, OED (2005d) and elsewhere.

${ }^{72}$ OED (1999a).

${ }^{73}$ Suggested by Birdsall (2004).

${ }^{74}$ Bannerjee and He (2003b).

${ }^{75}$ For example, why are donors supporting the rollout of networked computer centres in schools in lowincome countries when there is little evidence of pedagogical cost-effectiveness and strong grounds for believing such interventions are unsustainable when there are strong, repeated and rigorous evaluations if interactive radio instruction suggesting significant educational returns and favorable benefit-cost ratios (see Grace and Kenny, 2003).

${ }^{76}$ This last calculated from data in Chen and Ravallion (2001).

${ }^{77}$ Collier and Dollar (1999).

${ }^{78}$ Bannerjee and He (2005a). Lankester (2004) points out that the moral case for aid may be strongest in the cases where they cannot rely on their own governments at all to act as their economic guardians suggesting the strength of the need-efficacy tradeoff. Gunning (2005) notes that the last ten years have seen aid going increasingly to countries with low CPIA ratings, and this applies especially to multilateral institutions. Perhaps this reflects a stronger poverty focus.

${ }^{79}$ See also Moss and Subramanian (2005).

${ }^{80}$ Moss (2005).

${ }^{81}$ A final suggestion: for the World Bank in particular, the institution has its own views on the purposes of aid and the best methods of delivery. Given that, it might be that the institution has a role as a 'countercyclical giver' -providing more programmatic resources to countries which, due to political and historical 
factors, receive less from bilateral donors, or to countries which, given their institutional strength, deserve more aid than they are currently receiving.

${ }^{82}$ It is worth noting that, as Lankester (2004) points out, even today's evaluations are more rigorous than many. "The ex post evaluation systems at the Bank and at DfID stand up very well when compared with the evaluation systems, such as they are, for the UK's domestic spending programs.” 


\section{Bibliography}

Alesina, A. and D. Dollar (2000) Who Gives Aid to Whom and Why? Journal of Economic Growth 5, 1.

Banerjee, A. and R. He (2003a) The World Bank of the Future American Economic Review 93,2.

Banerjee, A. and R. He (2003b) Making Aid Work mimeo, MIT.

Barder, O. (2005) Making Markets for Vaccines -Ideas to Action, Center for Global Development Brief, 04/07/2005.

Bell, C. and C. Fink (2004) Aid and Health, paper presented at the Second Annual AfD/EUDN Conference, Paris, 25 November.

Bhaumik, S. (2005) Does the World Bank Have Any Impact on Human Development of the Poorest countries? Some Preliminary Evidence from Africa, William Davidson Institute Working Paper 784, University of Michigan.

Birdsall, N. (2004) Seven Deadly Sins: Reflections on Donor Failings Center for Global Development Working Paper No. 40.

Boone, P. (1996) Politics and the Effectiveness of Foreign Aid European Economic Review 40 (February).

Brautigam, D. and S. Knack (2004) Foreign Aid, Institutions, and Governance in SubSaharan Africa Economic Development and Cultural Change 52.

Butkiewicz, J. and H. Yanikkaya (2005) The Effects of IMF and World Bank Lending on Long-Run Economic Growth: An Empirical Analysis World Development 33, 3.

Chauvin, N. and A. Kraay (2005) What Has 100 Billion dollars Worth of Debt Relief Done for Low Income Countries mimeo, World Bank.

Chen, S. and M. Ravallion (2001) How Did the World's Poorest Fare in the 1990s? Review of Income and Wealth September.

Clemens, M. (2002) World Bank Capital Neither Complements nor Substitues for Private Capital, Center for Global Development Working Paper 20

Clemens, M. and T. Moss (2005) Ghost of 0.7\%: Origins and Relevance of the International Aid Target, Center for Global Development Working Paper 68.

Clemens, M., C. Kenny and T. Moss (2004) The Trouble with the MDGs: Confronting Expectations of Aid and Development Success, Center for Global Development Working Paper 40.

Clemens, M., S. Radalet and R. Bhavni. (2004) Counting Chickens When They Hatch: The Short-term Effect of Aid on Growth, Center for Global Development Working Paper 44.

Collier, P. and J. Dehn (2001) Aid, Shocks and Growth World Bank Policy Research Working Paper 2688 
Cordella, T. and G Dell’Ariccia (2003) Budget Support Versus Project Aid IMF Working Paper WP/03/88.

Coviello, D. and R. Islam (2006) Does Aid Help Improve Economic Institutions? World Bank Policy Research Working Paper 3990.

Das, J., S. Dercon, J. Habyarimana and P. Krishnan (2004) When Can School Inputs Improve Test Scores? CSAE Working Paper 2004-25.

Devarajan, S., W. Easterly and H. Pack (2002) Low Investment is Not the Constraint on African Development Center for Global Development Working Paper 13.

Djankov, S., J Montalvo and M. Reynal-Querol (22005) The Curse of Aid, mimeo, World Bank.

Dollar, D. and P. Collier (1999) Aid Allocation and Poverty Reduction World Bank Policy Research Working Paper 2041

Dollar, D. and V. Levin (2005) Sowing and Reaping: Institutional Quality and Project Outcomes in Developing Countries World Bank Policy Research Working Paper 3524.

Doucouliagos, H. and M. Paldam (2005a) Aid Effectiveness on Growth: A Meta Study, University of Aarhus Department of Economics Working Paper 2005-15/6.

Doucouliagos, H. and M. Paldam (2005b) Aid Effectiveness on Accumulation: A Meta Study, University of Aarhus Department of Economics Working Paper 2005-12.

Doucouliagos, H. and M. Paldam (2005c) The Aid Effectiveness Literature: The Sad Results of 40 Years of Research, University of Aarhus Department of Economics Working Paper 2005-15/6.

Dreher, A. (2005) IMF and Economic Growth: The Effects of Programs, Loans and Compliance with Conditionality World Development, 34, 5.

Dunning, T. (2004) Conditioning the Effects of Aid: Cold War Politics, Donor Credibility, and Democracy in Africa International Organization, 58, 2.

Durbarry, R. (2004) Foreign Aid: Is it All Consumed? Journal of International Development 16, 189-99.

Easterly, W. (2002) What Did Structural Adjustment Adjust? The Association of Policies and Growth with Repeated IMF and World Bank Adjustment Loans, Center for Global Development Working Paper 11.

Easterly, W. (2005) Reliving the 50s: The Big Push, Poverty Traps and Takeoffs in Economic Development mimeo, New York University.

Easterly, W. and R. Levine (2002) Tropics, Germs and Crops: How Endowments Influence Economic Development, NBER Working Paper 9106.

Easterly, W., R. Levine and D. Roodman (2003) New Data, New Doubts: A Comment on Burnside and Dollar’s “Aid, Policies and Growth” NBER Working Paper 9846.

Easterly. W. (1999) The Ghost of Financing Gap: Testing the Growth Model Used in the International Financial Institutions Journal of Development Economics 60 (2). 
Filmer, D. (2004) If You Build It, Will They come? School Availability and School Enrollment in 21 Poor Countries World Bank Policy Research Working Paper 3340

Goldsmith, A. (2000) Foreign Aid and Statehood in Africa USAID African Economic Policy Discussion Paper 47.

Gomanee, K., S. Girma and O. Morrissey (2005) Aid and Growth in Sub-Saharan Africa: Accounting for Transmission Mechanisms, Centre for Research in Economic Development and International Trade, University of Nottingham No. 02/05.

Gunning, J. (2005) Why Give Aid? Paper presented at the $2^{\text {nd }}$ AFD-EUDN Conference Development Aid: Why and How, Paris, November 25 2004.

Gupta, S., B. Clements A. Pivovarsky and E. Tiongson (2003) Foreign Aid and Revenue Response: Does the Composition of Aid Matter IMF Working Paper 08/08/2003.

Hanmer, L., R. Lensink and H. White (2003) Infant and Child Mortality in Developing Countries: Analysing the Data for Roust Determinants Journal of Development Studies 40, 1.

Harford, T., B. Hadjimichael and M. Klein (2004) Aid Agency Competition: A Century of Entry, But No Exit. World Bank Public Policy for the Private Sector Note 277.

Johnson, D. and T. Zajonc (2006) Can Foreign Aid Create and Incentive for Good Governance? Evidence from the Millennium Challenge Corporation, mimeo, Harvard University, April.

Kanbur,, R. and T. Sandler (1999) The Future of Development Assistance: Common Pools and International Public Goods ODC Policy Essay No. 25.

Kenny (2005) There’s (Much) More to Life than Income: The Weak Link Between Income, Health and Education mimeo, World Bank.

Kenny, C. and D. Williams (2001) What Do We Know About Economic Growth? Or, Why Don’t We Know Very Much? World Development 29,1.

Klein, M. and T. Harford (2005) Grants or Loans? Development Finance and Incentive Effects Public Policy for the Private Sector Note No. 287.

Knack, S. (1999) Aid Dependence and the Quality of Governance: A Cross-Country Empirical Analysis, mimeo, IRIS, University of Maryland.

Knack, S., and A. Rahman (2004) Donor Fragmentation and Bureaucratic Quality in Aid Recipients, World Bank Policy Research Working Paper 3186.

Kremer, M and E. Miguel (2004) Worms: Identifying Impacts on Education and Health in the Presence of Treatment Externalities Econometrica 72, 1.

Lankaster, T. (2004) International Aid: Experience, Prospects and the Moral Case World Economics 5,1.

Lerrick, A. (2005) Why is the World Bank Still Lending? Wall Street Journal 28/10/2005. 
Levine, R. (2004) Millions Saved: Proven Successes in Global Health Washington DC: Center for Global Development

Masud, N. and B. Yontcheva (2005) Does Foreign Aid Reduce Poverty? Empirical Evidence from Nongovernmental and bilateral Aid IMF Working Paper WP05/100.

McGillivray, M. (2005) Is Aid Effective? Mimeo, WIDER Helsinki.

Meltzer, A (Chair) (2000) Report of the International Financial Institution Advisory Commission, Washington DC: US Congress.

Moss, T. (2005) Ten Myths of the International Finance Facility, Center for Global Development Working Paper 60.

Moss, T., D. Roodman and S. Standley (2005) The Global War on Terror and US Development Assistance: USAID Allocation by Country 1998-2005. Center for Global Development Working Paper 62.

Moss, T., G. Pettersson and N. van de Walle (2006) An Aid-Institutions Paradox? A Review Essay on Aid Dependency and State Building in Sub-Saharan Africa, Center for Global Development Working Paper 74.

Nestmann, T. and B. Weder (2002) The Effectiveness of International Aid and Debt Relief: A Selective Review of the Literature, Paper prepared for the 5. Limburg Seminar on Financing and Development, mimeo, Department of Economics, University of Mainz.

Nkusu, M. (2004) Are There Negative Returns to Aid? A Comment IMF Working Paper $04 / 212$

OED (World Bank Operations Evaluation Department) (1999a) Development Effectiveness in Health Nutrition and Population: Lessons from World Bank Experience Washington DC: World Bank.

OED (World Bank Operations Evaluation Department) (1999b) Global Health: Meeting the Challenge Washington DC: World Bank.

OED (World Bank Operations Evaluation Department) (1999c) Sub-Saharan Africa:

Lessons from Four Sectors Washington DC: World Bank.

OED (World Bank Operations Evaluation Department) (2000a) Annual Review of Development Effectiveness Washington DC: World Bank.

OED (World Bank Operations Evaluation Department) (2000b) Poverty Reduction in the 1990s: The World Bank Strategy Washington DC: World Bank.

OED (World Bank Operations Evaluation Department) (2001) Annual Review of Development Effectiveness Washington DC: World Bank.

OED (World Bank Operations Evaluation Department) (2003) Annual Review of Development Effectiveness Washington DC: World Bank.

OED (World Bank Operations Evaluation Department) (2004) Annual Review of Development Effectiveness Washington DC: World Bank. 
OED (World Bank Operations Evaluation Department) (2005a) World Bank Support for Capacity Building in Africa Washington DC: World Bank.

OED (World Bank Operations Evaluation Department) (2005b) Improving Investment Climates: An Evaluation of World Bank Group Assistance Washington DC: World Bank.

OED (World Bank Operations Evaluation Department) (2005c) The Effectiveness of World Bank Support for Community-Based and -Driven Development Washington DC: World Bank.

OED (World Bank Operations Evaluation Department) (2005d) Improving the World Bank's Development Effectiveness: What Does Evaluation Show? Washington DC: World Bank.

Przeworski, A. and J. Vreeland (2000) The Effect of IMF Programs on Economic Growth Journal of Development Economics 62, 385-421.

Rajan, R. and A. Subramanian (2005a) What Undermines Aid's Impact on Growth? IMF Working Paper WP/05/126.

Rajan, R. and A. Subramanian (2005b) Aid and Growth: What Does the Cross-Country Evidence Really Show? NBER Working Paper 11513.

Ranis, G. and F. Stewart (2001) Growth and Human Development: Comparative Latin American Experience Yale Economic Growth Center Discussion Paper No. 826.

Reddy, S. and C. Minoiu (2006) Development Aid and Economic Growth: A Positive Long-Run Relation, mimeo, Columbia University, New York.

Roodman, D. (2004) The Anarchy of Numbers: Aid, Development and Cross-Country Empirics, Center for Global Development Working Paper 32.

Roodman, D. (2004) Aid Project Proliferation and Absorptive Capacity, Center for Global Development Working Paper 75.

Ruhashyankiko, J. (2005) Why Do Some Countries Manage to Extract Growth from Foreign Aid? IMF Working Paper 05/53.

Sachs, J., J. W. McArthur, G. Schmidt-Traub, M. Kruk, C. Bahadur, M. Faye, and G. McCord, (2004), “Ending Africa’s Poverty Trap” Brooking Papers on Economic Acitivity, 2004 (1).

Svensson, J. (2000) Foreign Aid and Rent-seeking Journal of International Economics 51 437-461.

Van de Walle, D. and D. Cratty (2005) Do Donors Get What they Pay For? Micor Evidence on the Fungibility of Development Project Aid World Bank Policy Research Working Paper 3542.

Wane, W. (2004) The Quality of Foreign Aid: Country Selectivity or Donors Incentives World Bank Policy Research Working Paper 3325.

World Bank (1998) Assessing Aid: What Works, What Doesn't and Why New York: Oxford University Press. 